\title{
Isotopic and chromatographic fingerprinting of the sources of dissolved organic carbon in a shallow coastal aquifer
}

\author{
Karina T. Meredith ${ }^{1,2}$, Andy Baker ${ }^{2,3}$, Martin S. Andersen ${ }^{2,4}$, Denis M. O'Carroll ${ }^{2,4}$, Helen Rutlidge ${ }^{2,4}$, \\ Liza K. McDonough ${ }^{2,3}$, Phetdala Oudone ${ }^{2,3}$, Eliza Bryan ${ }^{5}$, and Nur Syahiza Zainuddin ${ }^{6}$ \\ ${ }^{1}$ Australian Nuclear Science and Technology Organisation, Lucas Heights, NSW 2234, Australia \\ ${ }^{2}$ Connected Waters Initiative Research Centre, UNSW Sydney, High St., Kensington, New South Wales 2052, Australia \\ ${ }^{3}$ School of Biological, Earth and Environmental Sciences, UNSW Sydney, High St., Kensington, \\ New South Wales 2052, Australia \\ ${ }^{4}$ School of Civil and Environmental Engineering, UNSW Sydney, High St., Kensington, New South Wales 2052, Australia \\ ${ }^{5}$ Golder Associates, 124 Pacific Highway, St. Leonards, Sydney, New South Wales 2065, Australia \\ ${ }^{6}$ Faculty of Civil Engineering, Universiti Teknologi MARA, Shah Alam, Selangor, Malaysia
}

Correspondence: Karina T. Meredith (kmj@ansto.gov.au)

Received: 19 December 2018 - Discussion started: 12 February 2019

Revised: 20 February 2020 - Accepted: 25 March 2020 - Published: 30 April 2020

\begin{abstract}
The terrestrial subsurface is the largest source of freshwater globally. The organic carbon contained within it and processes controlling its concentration remain largely unknown. The global median concentration of dissolved organic carbon (DOC) in groundwater is low compared to surface waters, suggesting significant processing in the subsurface. Yet the processes that remove this DOC in groundwater are not fully understood. The purpose of this study was to investigate the different sources and processes influencing DOC in a shallow anoxic coastal aquifer. Uniquely, this study combines liquid chromatography organic carbon detection with organic $\left(\delta^{13} \mathrm{C}_{\mathrm{DOC}}\right)$ carbon isotope geochemical analyses to fingerprint the various DOC sources that influence the concentration, carbon isotopic composition, and character with respect to distance from surface water sources, depth below surface, and inferred groundwater residence time (using ${ }^{3} \mathrm{H}$ activities) in groundwater. It was found that the average groundwater DOC concentration was 5 times higher $\left(5 \mathrm{mg} \mathrm{L}^{-1}\right)$ than the global median concentration and that the concentration doubled with depth at our site, but the chromatographic character did not change significantly. The anoxic saturated conditions of the aquifer limited the rate of organic matter processing, leading to enhanced preservation and storage of the DOC sources from peats and palaeosols contained within the aquifer. All groundwater samples were more aromatic for their molecular weight in comparison to
\end{abstract}

other lakes, rivers and surface marine samples studied. The destabilization or changes in hydrology, whether by anthropogenic or natural processes, could lead to the flux of up to 10 times more unreacted organic carbon from this coastal aquifer compared to deeper inland aquifers.

\section{Introduction}

Organic matter (OM) in aquatic systems forms a fundamental part of the global carbon cycle. The soil and unsaturated zone has the potential to store at least 3 times more organic carbon than in the atmosphere or in living plants (Schmidt et al., 2011; Fontaine et al., 2007) and represents the largest source of carbon within terrestrial ecosystems (Keiluweit et al., 2017). The below-ground environment forms the largest source of freshwater, and the organic carbon within these systems remains largely unaccounted for in the global carbon budget. Groundwater replenishment can occur either as diffuse recharge through the OM-rich soil zone or as indirect recharge originating from streams and wetlands that have the potential to contain high concentrations of OM. Despite the many sources of OM, groundwater dissolved organic carbon (DOC) concentrations are typically low $\left(\sim 1 \mathrm{mg} \mathrm{L}^{-1}\right.$ for the global median DOC concentration; McDonough et al., 2020a), suggesting significant processing in the subsurface. 
Very few studies have investigated why concentrations of DOC in groundwater are low. Recent research provided evidence of the attenuation of chromophoric dissolved organic matter (DOM) at a scale of tens of metres along a flow path with measurements of increased optical clarity of groundwater (Chapelle et al., 2016). This attenuation was proposed to be due to the combined effects of biodegradation and sorption. Chapelle et al. (2016) also showed that the presence of a hyperbolic relationship between DOC concentrations and dissolved oxygen provided indirect evidence for groundwater DOC that is bioavailable to microbes. Direct monitoring of groundwater DOC within a fractured rock aquifer in South Carolina, USA, which included measurements of both bioavailable and chromophoric DOM, was performed by Shen et al. (2015). They demonstrated a decrease in lignin-derived phenols in groundwater compared to surface inputs and prevalent amino acids in groundwater. At this site, it was proposed that a small fraction $(8 \% \pm 4 \%)$ of groundwater DOC was bioavailable and that a substantial fraction of groundwater DOC was of bacterial origin (15\%$34 \%)$. Shen et al. (2015) suggested that DOM mobility could be described by a regional chromatography model (Hedges et al., 1986, 1994) as it moved through the soil column to the groundwater. It was shown that the molecular size, polarity, charge and bioavailability determined the observed decrease in hydrophobicity of DOM along the flow path due to their controls on sorption, desorption, biodegradation and biosynthesis (Shen et al., 2015).

Carbon isotope ratios were first used in the 1960s to distinguish sources of $\mathrm{OM}$ in the coastal zone in order to identify the difference between salt-marsh sediments and freshwater peats (Emery et al., 1967). The use of carbon isotopes as tracers has been instrumental in providing greater understanding of the sources of carbon in coastal, terrestrial and marine environments (Benner et al., 1984; Lamb et al., 2006). Very few studies that used DOM chromatographic techniques also employed isotopic techniques to understand the source of OM in groundwater and vice versa. The use of multiple DOM characterization techniques to improve our understanding of the role of different OM sources in contributing to the concentration, character, and its subsequent processing along groundwater flow paths is therefore in its early stages of research.

Further work is clearly warranted to improve our understanding of the role of different OM sources and the physicochemical properties of the aquifer on groundwater DOM. To this end, we present groundwater DOC concentration, stable carbon isotopic signatures $\left({ }^{13} \mathrm{C}\right)$ and organic matter character data from a shallow (less than $20 \mathrm{~m}$ in depth) anoxic coastal aquifer. Within this hydrogeologically well characterized system, it is anticipated that multiple sources of OM exist including wetland, soil, peat and palaeosols. To better understand and test the regional chromatography model, we utilize a chromatographic technique (liquid chromatography organic carbon detection - LC-OCD; Huber et al., 2011). Uniquely, this study combines the chromatographic tech-

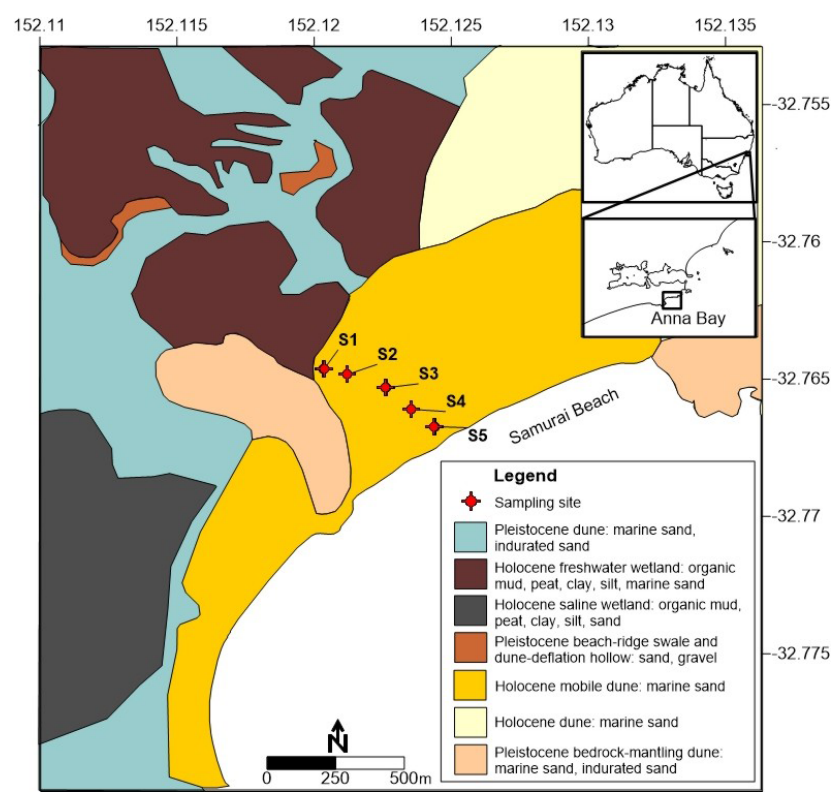

Figure 1. Location of the study area and groundwater monitoring wells in relation to coastal quaternary geology (adapted from Hashimoto and Toedson, 2008).

nique with organic isotope geochemical analyses to fingerprint the various DOC sources that influence concentration, $\delta^{13} \mathrm{C}_{\mathrm{DOC}}$ and character with respect to distance, depth and inferred groundwater residence time (using ${ }^{3} \mathrm{H}$ activities). This was done to identify controls on groundwater DOC sources and processing in a coastal groundwater system.

\section{Environmental setting}

The coastal environment of Samurai Beach is located northeast of Anna Bay, New South Wales, Australia (Fig. 1). The Holocene sand dunes at the site rise $30 \mathrm{~m}$ above sea level and extend up to $800 \mathrm{~m}$ inland. A freshwater wetland and forest lie in the northwest corner of the sand dunes near Site 1 (S1), and the aquifer is part of the Tomaree groundwater source supplying towns in the Hunter Valley with potable water. The local geology of the field site was investigated during borehole construction and using hydraulic profiling tools to produce the lithology cross section depicted in Fig. 2 (Maric, 2013; Howley, 2014). The lithological cross section is parallel with the main groundwater flow direction from the wetland to the coast.

The upper $15 \mathrm{~m}$ of the aquifer contained a combination of barrier and back barrier sand deposits, capped by aeolian dune deposits. Site 1 was located in the northwest corner closest to the freshwater wetland, while Site 5 (S5) was closest to the Pacific Ocean. The lithology of the aquifer differs with distance along the transect with a peat layer identified at $\sim 5 \mathrm{~m}$ below ground level at sites 1 and 2 and a clay unit 
at Site 5 (Fig. 2). A shallower organic-rich layer was also identified at about $1 \mathrm{~m}$ b.g.l. (below ground level) at $\mathrm{S} 1$.

Five sites were drilled and wells installed to three different depths: shallow (S_3.4 to 5.0 m b.g.1.), medium (M_9.8 to $12.5 \mathrm{~m}$ ) and deep (D_12.7 to $17.5 \mathrm{~m}$ ), which formed a $\sim 500 \mathrm{~m}$ long transect. The boreholes were drilled by hollow stem auger using a Geoprobe rig, and wells were constructed out of $50 \mathrm{~mm}$ diameter PVC with screened intervals of $1 \mathrm{~m}$ located at the bottom.

Three different sources of groundwater were identified based on hydrochemistry and the evaluation of groundwater flow direction (Maric, 2013; Howley, 2014). These groundwater sources included (1) direct rainfall recharge through the dunes, (2) indirect wetland infiltration and (3) deeper regional groundwater (Fig. 2). Multiple sources of OM may be present at the site from (1) surface vegetation, (2) transported particulate organic matter (POM) and/or (3) in situ sedimentary sources such as peat, palaeosol or finely disseminated POM.

\section{Methods}

From 17 to 22 February 2014, 15 groundwater samples were collected from the five nested sites (Fig. 1). Surface water samples were also collected from the adjacent wetland. Waters were measured for major ion chemistry, carbon isotopes $\left(\delta^{13} \mathrm{C}_{\text {DIC }}\right.$, where DIC represents dissolved inorganic carbon, and $\left.\delta^{13} \mathrm{C}_{\mathrm{DOC}}\right)$, tritium $\left({ }^{3} \mathrm{H}\right)$ and DOM character.

Groundwater samples were generally collected using a submersible centrifugal pump (Monsoon). A Hach multimeter (HQ40d) and probes (LDO probe) were used for dissolved oxygen and $\mathrm{pH}$ measurements in an inline flow cell (Waterra) isolated from the atmosphere. Subsamples for laboratory analysis were collected through an inline, $0.45 \mu \mathrm{m}$ filter (bypassing the flow cell) with $\delta^{13} \mathrm{C}_{\mathrm{DIC}}$ and $\delta^{13} \mathrm{C}_{\mathrm{DOC}}$ samples further filtered through a $0.22 \mu \mathrm{m}$ filter. Total alkalinity was determined in the field by Gran titration (Stumm and Morgan, 1996) using a Hach digital titrator (model 16900) and $0.16 \mathrm{~N} \mathrm{H}_{2} \mathrm{SO}_{4}$. Samples for anions were collected in $50 \mathrm{~mL}$ polyethylene centrifuge bottles with no further treatment, but they were stored cool $\left(\sim 5^{\circ} \mathrm{C}\right)$ and dark. Samples for cations were collected in $20 \mathrm{~mL}$ high-density polyethylene acid-washed bottles and acidified with $1 \%$ of concentrated nitric acid $\left(\mathrm{HNO}_{3}\right)$. The $\delta^{13} \mathrm{C}_{\mathrm{DIC}}$ samples were collected in $12 \mathrm{~mL}$ pre-combusted glass vials (Exetainers) with no head space. The DOC and $\delta^{13} \mathrm{C}_{\mathrm{DOC}}$ were collected in $60 \mathrm{~mL}$ acid-washed HDPE bottles and frozen within $12 \mathrm{~h}$ of collection. Samples for ${ }^{3} \mathrm{H}$ analysis were collected in $1 \mathrm{~L}$ Nalgene HDPE bottles and were sealed with tape to eliminate atmospheric exchange during storage. Major and minor cations were determined using a Perkin Elmer NexION 300D ICP-MS and a Perkin Elmer Optima 7300 ICP-OES. Anions (for $\mathrm{Cl}$ and $\mathrm{SO}_{4}$ ) were analysed using a Dionex IC1000 ion chromatography system. Cations and anions were assessed for accuracy by evaluating the charge balance error percentage (CBE\%; Table 2). Samples fell within the acceptable $\pm 5 \%$ range.

The $\delta^{13} \mathrm{C}_{\text {DIC }}$ isotopic ratios of waters were analysed with an isotope ratio mass spectrometer (IRMS), and the results were reported as per mil (\%o) deviations from the international carbonate standard, NBS 19, with a precision of $\pm 0.1 \%$, according to the methods reported in Meredith et al. (2016). The DOC concentration and $\delta^{13} \mathrm{C}_{\mathrm{DOC}}$ were analysed using a total organic carbon analyser interfaced with a PDZ Europa 20-20 IRMS utilizing a GD100 gas trap interface. Results were reported as \%o deviations from the NIST standard reference material with an analytical precision of $\pm 0.6 \%$ o. The ${ }^{3} \mathrm{H}$ activities were expressed in tritium units (TU) with an uncertainty of $\pm 0.1 \mathrm{TU}$ and a quantification limit of $0.3 \mathrm{TU}$. Samples were analysed by liquid scintillation counting. Extended methods for ${ }^{3} \mathrm{H}$ activities can be found in Meredith et al. (2012). Tritium activities were used as an indication of groundwater recharge occurrence by rainfall, and groundwater ages were not calculated due to a lack of time series data collected for this study. Bryan et al. (2020) show the importance of collecting ${ }^{3} \mathrm{H}$ data and then calculating a groundwater age using a lumped parameter model in a shallow unconfined aquifer.

The DOM character was determined using liquid chromatography organic carbon detection (LC-OCD). The LCOCD technique is a size-exclusion chromatographic technique that allows for the characterization of DOC, based on molecular weight, into six fractions. The fractions obtained are biopolymers $(>20 \mathrm{kDa})$, humic substances $(\sim 1000 \mathrm{Da})$, building blocks (300-500 Da), low molecular weight acids $(<350 \mathrm{Da})$, low molecular weight neutrals $(<350 \mathrm{Da})$ and a hydrophobic fraction (fraction of DOC that remains in the column and is determined by the difference between total DOC and the total of the other fractions); for full details see Huber et al. (2011). The humic substances fraction is further characterized for its molecular weight (based on the retention time of the humic substances peak) and aromaticity (the specific UV absorption at $254 \mathrm{~nm}$ of the humic substances peak). Calibration is based on the chromatograms of the Suwanee River humic and fulvic acid standards of the International Humic Substances Society (IHSS). Principal component analysis (PCA) was performed in R. Parameters which were consistently above their limit of detection were investigated by PCA. The data were centred to the mean of the variable and then scaled using the variable standard deviations in $\mathrm{R}$ and the prcomp function: https://stat.ethz.ch/R-manual/R-devel/library/stats/ html/prcomp.html (last access: 18 February 2020).

\section{Results}

Although common at coastal sites, a fresh-saline water interface was not identified in the wells, even though Site 5 is 


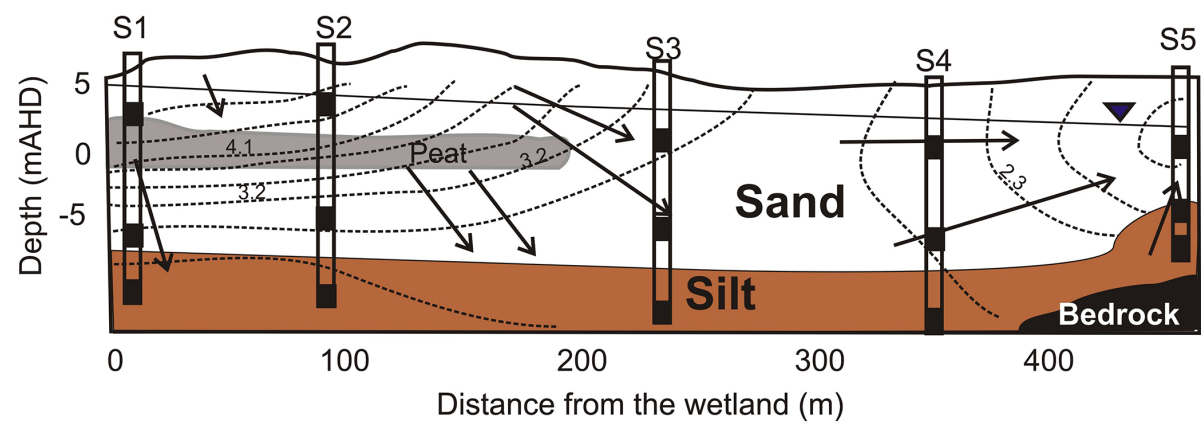

Figure 2. Lithology and potentiometric contours (in metres) in the aquifer in February 2014 (adapted from Maric, 2013; Howley, 2014). Open black rectangles represent groundwater wells, filled rectangles are the location of the well-screen intervals within the aquifer and arrows indicate groundwater flow direction.

Table 1. Water chemistry data for the site. Elevation of midpoint of the screen (m AHD), EC (electrical conductivity; $\mu \mathrm{S} \mathrm{cm}{ }^{-1}$ ), DO (dissolved oxygen; $\mathrm{mg} \mathrm{L}^{-1}$ ), $T$ (temperature; ${ }^{\circ} \mathrm{C}$ ), Eh (redox potential; $\left.\mathrm{mV}\right)$, cations and anions $\left(\mathrm{mg} \mathrm{L}^{-1}\right)$, and n.a. (not detected).

\begin{tabular}{|c|c|c|c|c|c|c|c|c|c|c|c|c|c|c|c|c|c|c|}
\hline ID & $\begin{array}{l}\text { Eleva- } \\
\text { tion }\end{array}$ & $\begin{array}{r}\text { Field } \\
\mathrm{pH}\end{array}$ & EC & DO & $T$ & Eh & $\mathrm{Ca}$ & $\mathrm{Fe}$ & K & $\mathrm{Mg}$ & $\mathrm{Mn}$ & $\mathrm{Na}$ & $\mathrm{Si}$ & $\mathrm{Sr}$ & $\mathrm{Cl}$ & $\mathrm{SO}_{4}$ & $\mathrm{NO}_{3}$ & $\mathrm{~N}-\mathrm{NH}_{4}$ \\
\hline S1_S & 2.9 & 7.19 & 495 & 0.06 & 22.1 & -97.2 & 81.20 & 3.27 & 0.81 & 4.12 & 0.08 & 23.11 & 2.56 & 0.70 & 40.21 & n.a. & n.a. & 0.22 \\
\hline S1_M & -6.1 & 6.1 & 337 & 0.04 & 19.6 & -14.5 & 38.60 & 1.40 & 0.97 & 7.96 & 0.02 & 24.05 & 2.11 & 0.35 & 43.03 & n.a. & n.a. & 0.14 \\
\hline S1_D & -10.4 & 5.36 & 215 & 0.04 & 20.4 & 7.8 & 7.91 & 0.58 & 1.15 & 3.65 & 0.01 & 32.00 & 5.27 & 0.08 & 38.19 & n.a. & 0.18 & 0.80 \\
\hline S2_S & 3.4 & 8.2 & 293 & 0.12 & 22.8 & -59.2 & 45.80 & 0.07 & 0.49 & 4.46 & 0.01 & 10.98 & 2.23 & 0.36 & 21.75 & 1.07 & n.a. & 0.00 \\
\hline S2_M & -5.3 & 6.03 & 408 & 0.06 & 21.2 & -42.9 & 45.31 & 0.17 & 1.66 & 14.54 & 0.01 & 24.65 & 2.04 & 0.35 & 43.69 & n.a. & 0.16 & 0.40 \\
\hline S2_D & -10.5 & 5.32 & 231 & 0.06 & 20.8 & -6.7 & 8.19 & 0.41 & 1.20 & 6.75 & 0.01 & 30.49 & 5.80 & 0.08 & 40.69 & n.a. & 0.28 & 0.90 \\
\hline S3_S & 1.0 & 7.24 & 306 & 0.17 & 24.1 & -42.9 & 45.95 & 0.23 & 0.54 & 4.58 & 0.01 & 12.36 & 2.67 & 0.36 & 19.48 & 4.45 & n.a. & 0.03 \\
\hline S3_M & -5.7 & 6.98 & 282 & 0.04 & 21.4 & -47.8 & 43.93 & 0.05 & 0.63 & 4.24 & 0.02 & 13.19 & 2.63 & 0.33 & 20.34 & 5.20 & n.a. & 0.08 \\
\hline S3_D & -11.9 & 6.5 & 245 & 0.05 & 21.9 & -40.6 & 10.67 & 0.25 & 1.00 & 18.56 & 0.01 & 13.68 & 1.49 & 0.06 & 22.24 & 11.61 & n.a. & 0.81 \\
\hline S4_S & 0.1 & 6.59 & 323 & 0.1 & 21.9 & -28.1 & 47.49 & 0.03 & 1.09 & 5.81 & 0.01 & 14.02 & 1.88 & 0.37 & 22.40 & 0.67 & n.a. & 0.57 \\
\hline S4_M & -6.3 & 6.26 & 268 & 0.03 & 22 & -49 & 24.71 & 0.21 & 1.33 & 10.35 & 0.01 & 17.26 & 1.65 & 0.18 & 27.44 & 0.10 & n.a. & 0.84 \\
\hline S4_D & -12.8 & 6.24 & 319 & 0.04 & 22.4 & 5.5 & 7.44 & 0.22 & 1.38 & 27.28 & 0.03 & 18.44 & 2.57 & 0.04 & 29.06 & n.a. & n.a. & 0.51 \\
\hline S5_S & 0.1 & 6.69 & 365 & 0.06 & 21.8 & -62.5 & 51.22 & 0.71 & 1.10 & 5.96 & 0.00 & 19.13 & 2.43 & 0.42 & 31.16 & 10.18 & n.a. & 0.16 \\
\hline S5_M & -4.6 & 6.1 & 316 & 0.04 & 22.1 & -46.5 & 7.89 & 0.31 & 2.25 & 21.38 & 0.03 & 26.61 & 3.39 & 0.06 & 37.46 & n.a. & 0.14 & 0.69 \\
\hline S5_D & -7.4 & 6.16 & 348 & 0.1 & 21 & -58.4 & 8.10 & 0.59 & 2.89 & 22.39 & 0.04 & 34.13 & 3.72 & 0.07 & 43.15 & n.a. & 0.17 & 0.43 \\
\hline WS & 5.3 & 5.48 & 200 & 1.01 & 21.7 & 87.1 & 8.00 & 0.43 & 2.18 & 2.74 & 0.01 & 28.01 & 1.23 & 0.07 & 54.23 & 3.93 & n.a. & 0.03 \\
\hline
\end{tabular}

located $\sim 100 \mathrm{~m}$ from the ocean and there was no evidence of seawater infiltration after storm events based on the hydrochemical data. Groundwater had low salinities with $\mathrm{Cl}$ concentrations ranging from $0.5-1.2 \mathrm{mmol} \mathrm{L}^{-1}$. The highest $\mathrm{Cl}$ concentration occurred in the deeper groundwater at sites 1 and 2 (Table 1 and Fig. 3a). Water level data suggested that under most conditions groundwater followed a west to east direction towards the coastline (Fig. 2). Notably, groundwaters were anoxic with dissolved oxygen below $0.2 \mathrm{mg} \mathrm{L}^{-1}$ (Table 1). Water level patterns suggested that a buried-peat layer identified at sites 1 and 2 was restricting the vertical flow of rainfall-derived recharge into the deeper sections of the aquifer at these two sites.

The presence of detectable ${ }^{3} \mathrm{H}$ in all samples $(>0.7 \mathrm{TU})$ indicates that the groundwater had a component of water that had been in contact with the atmosphere during the past decade. Variations in ${ }^{3} \mathrm{H}$ contents were seen with depth and distance from the wetland, suggesting groundwaters had varied water residence times (Fig. 3b). The wetland had the highest ${ }^{3} \mathrm{H}$ content (1.7 TU) and represented a rainfall value for the region (Tadros et al., 2014). All wells located between 3.4 to $12.5 \mathrm{mb}$.g.l. had high ${ }^{3} \mathrm{H}$ contents greater than 1.2 TU. Groundwaters from Site 3 had consistent values around 1.5 TU, suggesting a similar source of water and that the aquifer is hydraulically connected at this site. Deeper groundwaters (other than Site 3) had lower ${ }^{3} \mathrm{H}$ values (less than $1 \mathrm{TU}$ ), indicating slightly older groundwater at depth (Table 2).

The average DOC concentration in groundwater for this site was high $\left(5.0 \mathrm{mgL}^{-1} ; n=15\right)$ compared to the $\sim$ $1 \mathrm{mgL}^{-1}$ for the global median DOC concentration in groundwater (McDonough et al., 2020a). The carbon isotopic signature of the groundwater DOC represented a $\mathrm{C}_{3}$ vegetation signature (average $\delta^{13} \mathrm{C}_{\mathrm{DOC}}$ value of $-27.4 \%$; $n=15$ ). Significant variation in DOC concentration and $\delta^{13} \mathrm{C}_{\mathrm{DOC}}$ values occurred within the aquifer (Fig. 4). The increase in DOC concentration in deeper groundwaters compared to shallow groundwaters (except Site 4) suggested a source(s) of DOC within the aquifer, which is generally not seen in groundwater environments and will be discussed below. 


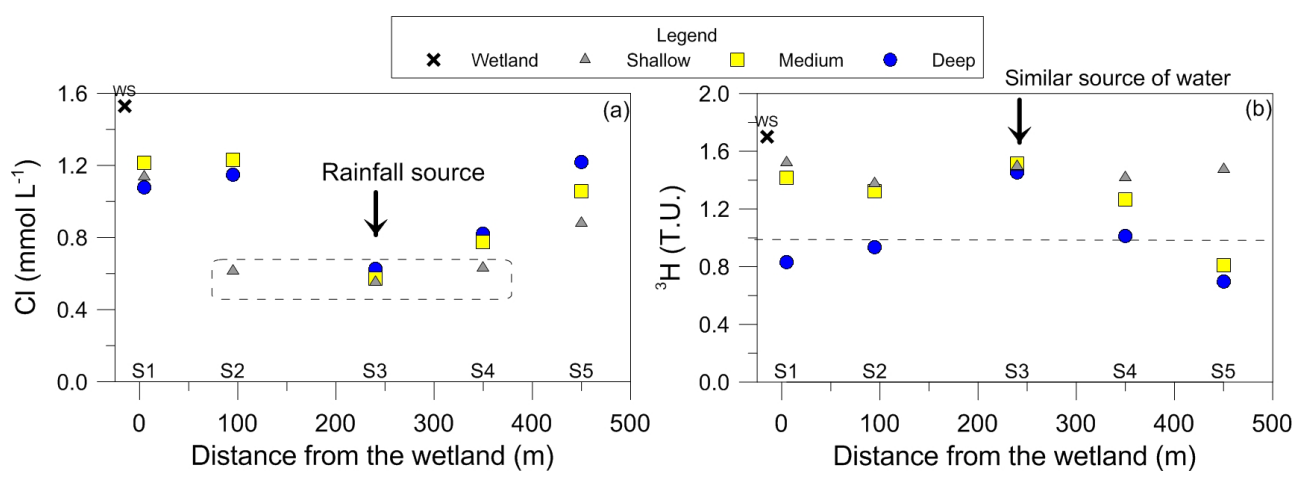

Figure 3. The relationship between (a) chloride concentration $\left(\mathrm{mmol} \mathrm{L}^{-1}\right)$ with the dashed rectangle representing rainfall values and (b) tritium (TU) content with distance from the wetland with the dotted line representing recently recharged groundwaters (i.e. between 1 to 5 years old).

Table 2. Environmental isotope data for the site. DOC (dissolved organic carbon), uncert (tritium uncertainty), QL (tritium quantification limit), $\mathrm{CBE}$ (charge balance error), $\mathrm{SI}_{\mathrm{cc}}$ (saturation index for calcite), and $P_{\mathrm{CO}_{2}}$ (partial pressure of carbon dioxide).

\begin{tabular}{|c|c|c|c|c|c|c|c|c|c|c|c|}
\hline ID & Date & $\begin{array}{r}\delta^{13} \mathrm{C}_{\mathrm{DIC}} \\
(\% \circ)\end{array}$ & $\begin{array}{l}\text { DOC } \\
\text { ppm }\end{array}$ & $\begin{array}{r}\delta^{13} \mathrm{C}_{\mathrm{DOC}} \\
(\% \circ)\end{array}$ & $\begin{array}{l}{ }^{3} \mathrm{H} \\
\mathrm{TU}\end{array}$ & $\begin{array}{r}{ }^{3} \mathrm{H} \text { uncert } \\
\mathrm{TU}\end{array}$ & $\begin{array}{l}\text { QL } \\
\text { TU }\end{array}$ & $\begin{array}{r}\mathrm{CBE} \\
\%\end{array}$ & $\begin{array}{r}\text { DIC } \\
\mathrm{mmol} \mathrm{L}^{-1}\end{array}$ & $\mathrm{SI}_{\mathrm{cc}}$ & $\begin{array}{r}\mathrm{P}_{\mathrm{CO}_{2}} \\
\text { atm }\end{array}$ \\
\hline $\mathrm{S} 1$ _S & $18 / 02 / 2014$ & -11.8 & 5.0 & -29.3 & 1.52 & 0.07 & 0.15 & 0.10 & 4.97 & 0.03 & 0.016 \\
\hline S1_M & $18 / 02 / 2014$ & -10.5 & 8.8 & -28.9 & 1.41 & 0.07 & 0.15 & 1.25 & 6.64 & -1.64 & 0.107 \\
\hline S1_D & $18 / 02 / 2014$ & -4.1 & 9.5 & -27.4 & 0.83 & 0.05 & 0.16 & 1.69 & 11.31 & -3.37 & 0.265 \\
\hline S2_S & $19 / 02 / 2014$ & -14.0 & 0.3 & -28.6 & 1.37 & 0.07 & 0.15 & -0.54 & 2.53 & 0.59 & 0.001 \\
\hline S2_M & $18 / 02 / 2014$ & -4.2 & 10.6 & -28.3 & 1.32 & 0.06 & 0.15 & 0.74 & 9.91 & -1.50 & 0.175 \\
\hline S2_D & $18 / 02 / 2014$ & -2.6 & 10.5 & -27.8 & 0.94 & 0.05 & 0.16 & 0.62 & 14.23 & -3.33 & 0.340 \\
\hline S3_S & $19 / 02 / 2014$ & -14.8 & 0.4 & -27.1 & 1.49 & 0.08 & 0.16 & 0.87 & 2.88 & -0.33 & 0.009 \\
\hline S3_M & $19 / 02 / 2014$ & -12.3 & 1.3 & -26.7 & 1.51 & 0.08 & 0.16 & 0.94 & 2.99 & -0.66 & 0.015 \\
\hline S3_D & $19 / 02 / 2014$ & -12.3 & 4.2 & -26.6 & 1.45 & 0.07 & 0.16 & 2.54 & 3.14 & -1.86 & 0.034 \\
\hline S4_S & $20 / 02 / 2014$ & -9.0 & 5.6 & -26.8 & 1.42 & 0.07 & 0.15 & -0.07 & 4.48 & -0.95 & 0.043 \\
\hline S4_M & $20 / 02 / 2014$ & -11.0 & 3.6 & -26.5 & 1.27 & 0.07 & 0.16 & 0.14 & 4.71 & -1.67 & 0.069 \\
\hline S4_D & $20 / 02 / 2014$ & -7.2 & 4.3 & -26.5 & 1.01 & 0.06 & 0.15 & 0.90 & 5.83 & -2.13 & 0.088 \\
\hline S5_S & $21 / 02 / 2014$ & -12.9 & 2.1 & -25.0 & 1.47 & 0.07 & 0.16 & 0.89 & 4.13 & -0.83 & 0.034 \\
\hline S5_M & $21 / 02 / 2014$ & -9.1 & 4.5 & -26.7 & 0.81 & 0.05 & 0.16 & -0.34 & 6.49 & -2.28 & 0.111 \\
\hline S5_D & $21 / 02 / 2014$ & -9.4 & 3.8 & -26.4 & 0.69 & 0.04 & 0.16 & -0.47 & 6.66 & -2.19 & 0.105 \\
\hline WS & $20 / 02 / 2014$ & -23.6 & 18.0 & -30.3 & 1.70 & 0.08 & 0.15 & 4.40 & 1.56 & -3.96 & 0.037 \\
\hline
\end{tabular}

The LC-OCD results did not show significant differences in DOM character in the groundwater (Fig. 5). The fractions of humic substances were generally between $40 \%$ and $60 \%$ of the total DOC (Fig. 5a). Minor exceptions existed in the shallow samples at sites 2 and 3 for humic substances and at sites 2, 3 and 5 for the low molecular weight neutrals (LMW-Ns). The LMW-Ns were low, representing approximately $10 \%$ of the total DOM, and they did not change significantly along the groundwater flow path (i.e. with distance from the wetland) (Fig. 5b).

Principal component analysis (Fig. 6) using water quality parameters, isotopes and DOC variables included LCOCD fractions (\%), $\delta^{13} \mathrm{C}_{\text {DOC }}(\%), \delta^{13} \mathrm{C}_{\text {DIC }}(\%),{ }^{3} \mathrm{H}, \mathrm{pH}$, $\mathrm{Na}, p \mathrm{CO}_{2}, \mathrm{Cl}, \mathrm{Ca}, \mathrm{Sr}, \mathrm{DO}, \mathrm{SO}_{4}, \mathrm{NH}_{4}$ and DOC concentration and confirmed the presence of different groundwater sources. The variables contributing to $\mathrm{PC} 1$ in order of im- portance were $\mathrm{pH}, \mathrm{Na}, p \mathrm{CO}_{2}, \mathrm{Cl}$, DOC, $\mathrm{Ca}$, humics, LMW$\mathrm{N}, \mathrm{Sr}$ and ${ }^{3} \mathrm{H}$. The variables contributing to $\mathrm{PC} 2$ in order of importance were $\delta^{13} \mathrm{C}_{\mathrm{DOC}}$, DO, biopolymers, HS aromaticity, $\delta^{13} \mathrm{C}_{\text {DIC }}$, HS molecular weight, $\mathrm{Cl}$, DOC and hydrophobic DOM. PC1 mainly explained the variations with sample depth in the aquifer. Samples S1_D, S2_S, S2_D and S3_S were the samples that most strongly influenced PC1. The deep samples likely to have originated from a deeper regional source of water (S1_D and S2_D) influenced the right-hand side of the PCA with high $p \mathrm{CO}_{2}$, humic substances, $\mathrm{Na}$ and $\mathrm{Cl}$. These samples were also characterized by low $\mathrm{Ca},{ }^{3} \mathrm{H}$ and Sr. The shallow samples (S1_S, S2_S and S3_S) influenced the left-hand side of the PCA with low $p \mathrm{CO}_{2}$, humics, $\mathrm{Na}$, and $\mathrm{Cl}$ and had high $\mathrm{Ca},{ }^{3} \mathrm{H}$, and $\mathrm{Sr}$, which is suggestive of rainfall recharge waters. This analysis further highlighted the wetland sample that is not related to the other samples 

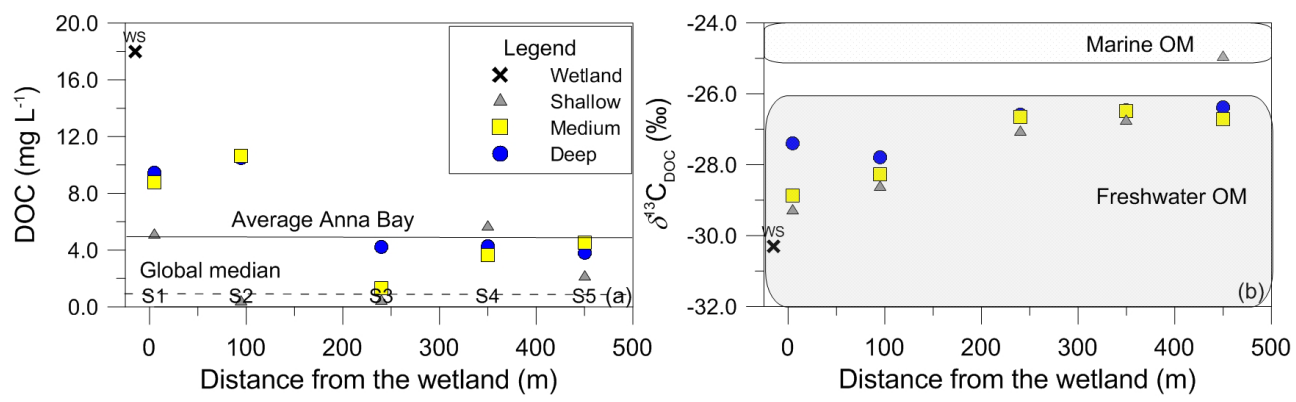

Figure 4. The relationship between (a) DOC concentration compared to average DOC for Anna Bay (solid black line) and global median DOC concentration for groundwater (dotted line) (McDonough et al., 2020a) and (b) $\delta^{13} C_{D O C}$ values for groundwaters from Anna Bay with distance from the wetland and compared to the terrestrial and marine OM ranges from Lamb et al. (2006).
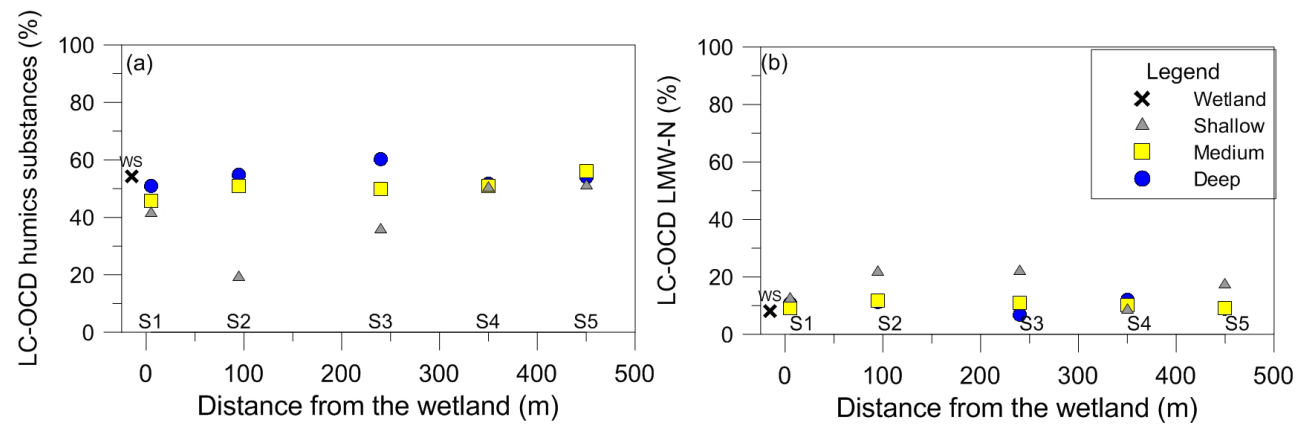

Figure 5. The relationship between (a) LC-OCD results with the total percentage of humic substances and (b) LC-OCD total percentage of low molecular weight neutrals with distance from the wetland.

(Fig. 6) and heavily influenced PC2 with low $\delta^{13} \mathrm{C}_{\mathrm{DOC}}$ values, high DO, high biopolymers, low HS aromaticity, low HS molecular weight and high DOC concentration.

\section{DOC variation in groundwater}

The wetland had the highest DOC $\left(18 \mathrm{mg} \mathrm{L}^{-1}\right)$ concentration and the lowest carbon isotope value $\left(\delta^{13} \mathrm{C}_{\mathrm{DOC}}=-30.3 \%\right.$ ) for the site. It also had a similar LC-OCD character to groundwater. The closest groundwater sample to the wetland, located less than $5 \mathrm{~m}$ downgradient at $3.5 \mathrm{~m}$ depth (S1_S), had a significantly lower DOC concentration $\left(5 \mathrm{mg} \mathrm{L}^{-1}\right)$ and $1 \%$ o higher carbon isotope value $\left(\delta^{13} \mathrm{C}_{\mathrm{DOC}}=-29.3 \%\right.$ ). Interestingly, this decrease in DOC was not reflected in the change in the mass fractions of the LC-OCD results.

The deeper samples $(>17.0 \mathrm{~m})$ at sites 1 and 2 had the highest DOC concentrations $\left(10 \pm 0.5 \mathrm{mg} \mathrm{L}^{-1}\right)$ for groundwaters at the site. The $\delta^{13} \mathrm{C}_{\mathrm{DOC}}$ values were higher in the deeper groundwaters $(-27.6 \pm 0.2 \%$ ) compared to the shallow samples $(-29.0 \pm 0.2 \%$ ). The humic substances aromaticity and molecular weight showed there were two distinct groups of DOM (Fig. 7). Samples that generally had lower values were from sites 1 and 2 and the wetland. All samples were more aromatic for their molecular weight in comparison to surface lakes, rivers and marine samples (Huber et al., 2011).
Groundwaters from sites 3-5 had lower DOC concentrations $\left(<6 \mathrm{mg} \mathrm{L}^{-1}\right.$ ) and a $1 \%$ higher average $\delta^{13} \mathrm{C}_{\mathrm{DOC}}$ value $(-26.6 \%)$ than shallow and medium groundwater samples from sites 1 and 2. Samples from sites 3, 4 and 5_S also had higher humic substances aromaticity and humic substances molecular weight than sites 1 and 2 (Fig. 7). The DOC did not show significant or consistent trends in aromaticity or molecular weight, nor did it show a trend of declining DOC concentration with depth or along a flow path.

\section{Discussion}

Our results showed that groundwater DOC varied in concentration and isotopic character along a $500 \mathrm{~m}$ groundwater flow path. The average groundwater DOC concentration found in this coastal site was 5 times higher $\left(5 \mathrm{mg} \mathrm{L}^{-1}\right)$ than the global median DOC concentration for groundwaters (McDonough et al., 2020a). The concentration of groundwater DOC doubled with depth, but we did not see any consistent trends in the DOM chromatographic character related to depth (Fig. 5). These results were in contrast to those from a deeper fractured rock aquifer (Shen et al., 2015), where DOC decreased with depth. Furthermore, despite observed differences in DOM characteristics (e.g. higher humic substances aromaticity and molecular weight in S3, S4 and S5_S), per- 


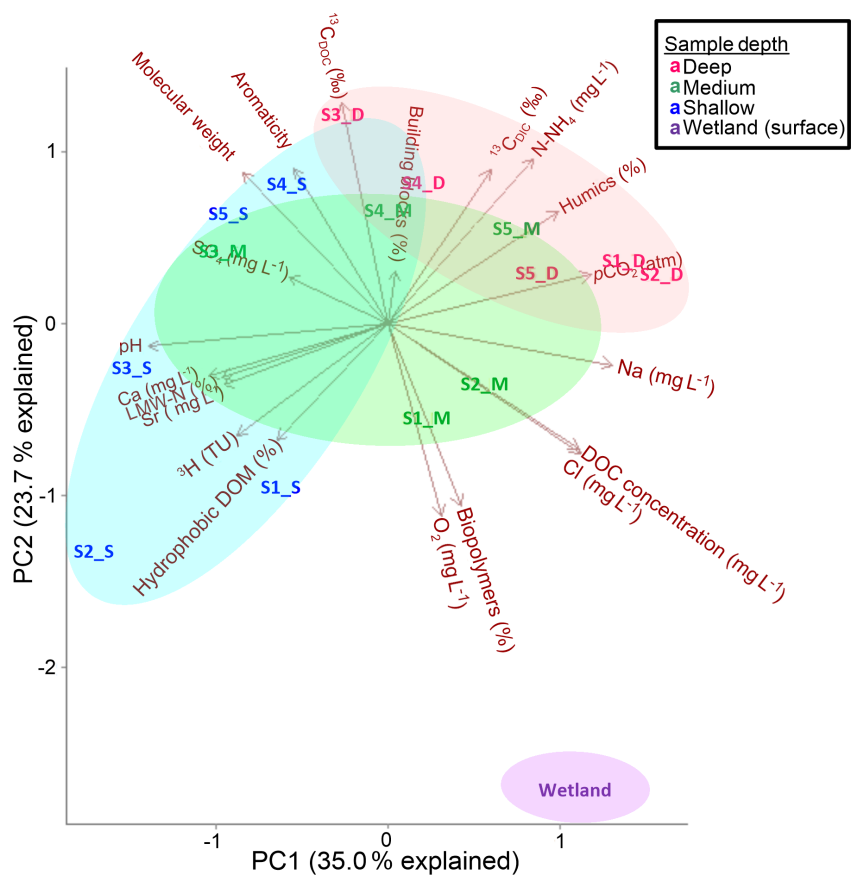

Figure 6. Principle component analysis for Anna Bay waters. The blue oval represents the shallow waters, the green oval represents the medium waters and the red oval represents the deeper waters. The wetland sample plots at the bottom of the graph with a distinct chemistry compared to the groundwater samples.

centages of LC-OCD fractions did not show any consistent trend along the groundwater flow path, contrary to what was found in other studies where biodegradation, sorption, desorption and biosynthesis controlled DOM (Chappelle et al., 2016; Shen et al., 2015). The experimental work of Oudone et al. (2019) also confirmed that sorption predominantly affects the humic substances fraction, especially with high aromaticity. If biodegradation were occurring, we would expect to see a decline in the biopolymer and low molecular weight neutral fractions (Catalán et al., 2017); however, we do not make a clear observation of this in our data. In contrast, Fig. 6 shows that the shallow samples located further from the wetland (S4_S and S5_S) have higher humic substances aromaticity and molecular weight, which supports the conclusion that sorption is not the dominant process determining DOM character from the wetland to the coastline.

Organic matter is more readily preserved under anoxic conditions (Bertrand and Lallier-Verges, 1993), particularly in saturated environments. In such systems, remineralization can be low, leading to enhanced preservation and storage of OM (Schefuß et al., 2016). Marine sediments, wetlands and peatlands have been suggested as having between $60 \%$ and $95 \%$ reduced mineralization rates (Keiluweit et al., 2017). The OM itself is thermodynamically unstable, but Schmidt et al. (2011) suggested it can persist because of the physicochemical and potentially biological influence of the sur-

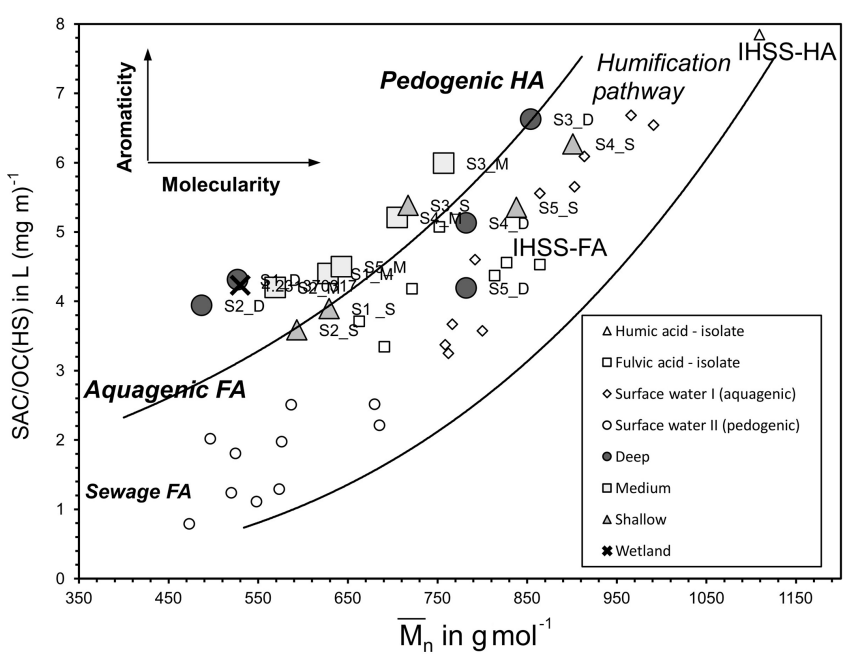

Figure 7. The relationship between humic substances molecular weight $\left(M_{n}\right)$ and humic substances aromaticity (SAC / OC represents spectral absorption coefficient / organic carbon). The curved lines show the area that samples would plot if the humic substances aromaticity and molecular weight are derived from the humic substances standard and water samples from Huber et al. (2011). The figure also indicates that the humic substances samples plotting at the top are interpreted as pedogenic in origin and that the fulvic acids at the bottom are aquagenic in origin. Note that humic acid (HA) and fulvic acid (FA) are isolated from the humic substances standard of the IHSS from Suwanee River (Huber et al., 2011). Surface water samples of humic-substances-aquagenic origin and humic-substances-pedogenic origin are also indicated.

rounding environment that reduces the rate of decomposition. Our hydrochemical data showed evidence to suggest OM degradation may have occurred. Dissolved oxygen was less than $0.2 \mathrm{mg} \mathrm{L}^{-1}$ for all groundwaters, which we inferred to be due to the respiration of microbes that have adapted to access $\mathrm{OM}$ in relatively anoxic conditions. Additional evidence for microbial activity included the presence of significant concentrations of reduced redox-sensitive species such as ammonium (up to $0.9 \mathrm{mg} \mathrm{L}^{-1}$ ) and ferrous iron (up to $3.3 \mathrm{mg} \mathrm{L}^{-1}$ ) together with very low nitrate concentration $\left(<0.3 \mathrm{mg} \mathrm{L}^{-1}\right)$, the absence of sulfate in the deeper groundwaters (Table 1) and the detection of $\mathrm{H}_{2} \mathrm{~S}$ odour. This fits with what was observed in anoxic subsurface environments where microbes utilize nitrate, iron oxides and sulfate as electron acceptors in the absence of oxygen, increasing the ammonia, ferrous iron and sulfide concentrations (Berner, 1981; Appelo and Postma, 2005). A possible explanation for the similar character of the DOM with the evolved inorganic redox chemistry is that the rates of biodegradation are far lower than the rate of DOM leaching into the groundwater. Furthermore, if there are additional sources of DOM along the flow path, we would expect to the see inconsistent variations in LC-OCD fractions along the flow path that we ob- 


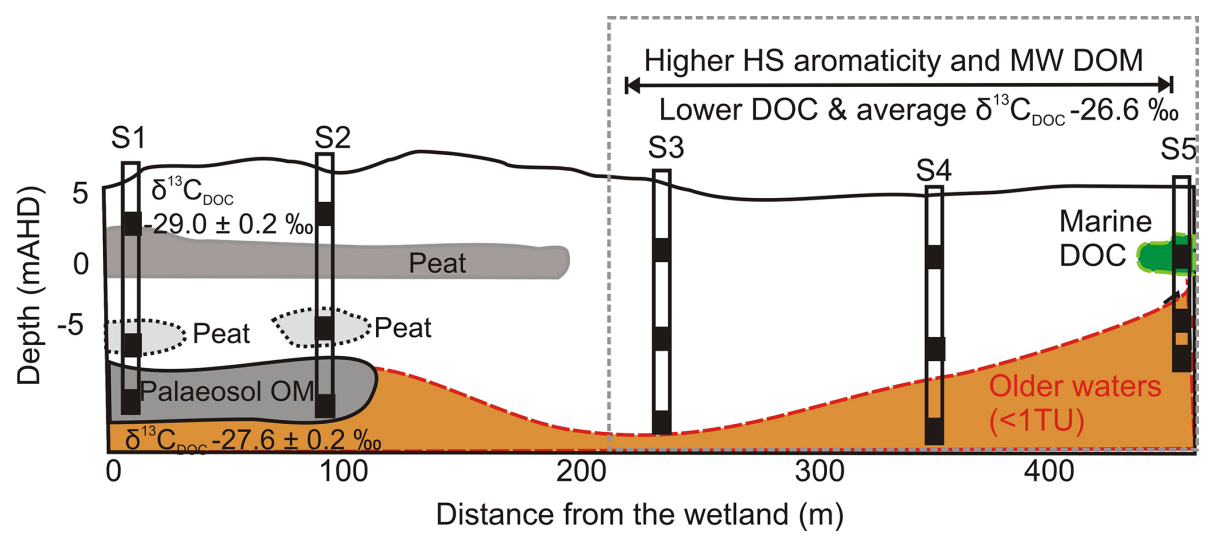

Figure 8. Schematic of OM sources and processes influencing DOC within the coastal aquifer at Anna Bay based on concentration, character (isotopic and chromatographic), tritium and hydrochemical data (Tables 1 and 2); marine and freshwater DOM characterization from Lamb et al. (2006).

serve in our data, rather than a consistent decline in any DOM fraction or DOC concentration.

\subsection{Sources of $\mathrm{OM}$}

Dissolved organic carbon in groundwater may originate from various sources. The most abundant source is generally from decomposing OM in the soil zone, and sedimentary OM from buried peat or palaeosols can also be a source (Clark and Fritz, 1997). The wetland organic-rich sediments, such as organic muds and silts associated with freshwater depressions, are characteristic of coastal dune-slack systems which have formed since the maximum Holocene sea-level transgression and have a global occurrence, including along the southeastern coast of Australia (MacPhail, 1974). These units have the potential to form peat. In suitable environments, the decay of OM under anaerobic conditions is much slower (Benner et al., 1984), allowing a greater accumulation of refractory OM, which may lead to peat accumulation (Lamb et al., 2006). Three "peat" horizons were identified in a similar coastal environment to Anna Bay (Fingal Bay, Central Coast, NSW) and ranged in age from 3.0 to $6.5 \mathrm{ka}$ (MacPhail, 1974). The peat formation was suggested to be very rapid, with metres of sediment accumulating over the past few thousand years.

The sand dunes at Anna Bay were likely to have formed around 7 ka (Sloss et al., 2007; Jones, 1990; MacPhail, 1974), and the OM-rich layers contained within them would have formed over this time. Organic matter can be characterized by very long turnover times that increase with depth from 1 to $10 \mathrm{ka}$ depending on the system (Schmidt et al., 2011). The radiocarbon age of DOC for the deeper groundwaters at S1_D and S2_D was measured by McDonough et al. (2020b) for the Anna Bay site. The results showed that DOC was $\sim 1 \mathrm{ka}(88.3 \pm 0.4 \mathrm{pMC})$ in the deeper groundwater samples, while the shallow water was modern (>100 pMC), suggesting an older OM source at depth. The destabilization of these older OM-rich units, whether by anthropogenic or natural processes, could result in an increase in the flux of older carbon into the surface water environment as observed by Moore et al. (2013), and the transport of this carbon has been shown to be dependent on the hydrological response in coastal systems (Webb et al., 2018).

\subsubsection{Wetland OM}

Initially, it was thought that the wetland was the major source of OM for the groundwater system because it contained elevated DOC concentrations $\left(18 \mathrm{mg} \mathrm{L}^{-1}\right)$ and appeared to be hydraulically connected to the aquifer. Based on these assumptions, it would mean that approximately $70 \%$ of the OM from the wetland would be removed after groundwater recharge (i.e. $10 \mathrm{~m}$ downgradient at sample S1_S at $3.5 \mathrm{~m}$ depth). This estimate seemed reasonable when considering that Shen et al. (2015) found that about $90 \%$ of surfacederived DOC was removed prior to reaching the saturated zone.

Our data showed that the chromatographic character of the DOM in the wetland was similar to that in the groundwater, suggesting that if the wetland was a significant source of OM, the chemical composition and bioavailability of the wetlandderived DOM remained relatively unchanged during transport through the aquifer. The higher relative contribution of DOC and evidence for the limited transformation of the wetland OM compared to groundwater at this site could also be explained by the limited sorption capacity of the predominantly quartz sand aquifer.

If biological processing was influencing the wetland DOM during transport into the groundwater, it would be expected that the $\delta^{13} \mathrm{C}_{\mathrm{DOC}}$ values would become heavier than the original $\mathrm{C}_{3}$ vegetation source - where the bacteria metabolize the isotopic light organics - because the ${ }^{12} \mathrm{C}-\mathrm{H}$ bonds are easier to break, leaving the resultant OM more enriched than the original source (Clark and Fritz, 1997). The carbon isotope value in the wetland was $1 \%$ o lighter compared to the shal- 
lowest groundwater sample located near the wetland. This suggests that a small amount of microbial processing may have occurred or that unprocessed DOM inputs are very high at this site.

Alternatively, because we do not observe clear decreases in DOC concentration or major changes in the LC-OCD fractions, the difference in isotopic values could be explained by the DOM in the groundwater system having a different source to the wetland and the limited interaction between the surface water and groundwater at this site. The lack of interaction would also explain the distinctly different water chemistry of the wetland sample compared to the groundwater (Table 1 and Fig. 6). The wetland contained elevated concentrations of DOC, but it is likely that the OM is being mobilized and deposited into the hyporheic zone of the wetland (i.e. 1-2 m) by either sorption or abiotic transformation (Kerner et al., 2003). This hypothesis is being investigated with further detailed water-sediment investigations at this location.

\subsubsection{In situ OM sources}

Organic-rich sediments were present in the unconsolidated aquifer units, and the physicochemical properties of the aquifer were governing the persistence of the OM within the aquifer. We see several in situ DOM sources based on the carbon isotopes and the humic substances aromaticity and molecular weight data (Fig. 7). Two major groundwater groups were identified at sites 1 and 2 and sites $3-5$. The aromaticity of the humic substances in both groups was higher than those previously reported for rivers and lakes for the corresponding molecular weight, especially for sites 3-5.

Furthermore, we see groupings for the deeper samples from sites 1 and 2 that corresponded with carbon isotopes that are $1 \%$ o higher $(-27.6 \pm 0.2 \%$ ) than other groundwater at sites 1 and 2 . These groundwaters contained less tritium, suggesting they were older $(<0.8 \mathrm{TU})$, and the $\mathrm{OM}$ is likely to have originated from the deeper, older palaeosol unit(s) contained within the coastal sediments (Fig. 8). The shallow groundwaters had lower DOC concentrations and lower carbon isotope values $(-29.0 \pm 0.2 \%$ ), suggesting the OM originating from these sources is also different from the deeper palaeosol. The overlying peat units most likely formed in a similar environment to the palaeosol located at depth but contained younger OM with lower source $\delta^{13} \mathrm{C}_{\mathrm{DOC}}$ values.

Groundwater from sites 3-5 had lower DOC concentrations $\left(<6 \mathrm{mg} \mathrm{L}^{-1}\right)$ and higher humic substances aromaticity and humic substances molecular weights (Fig. 7) together with higher consistent $\delta^{13} \mathrm{C}_{\mathrm{DOC}}$ values (average $\delta^{13} \mathrm{C}_{\mathrm{DOC}}$; $-26.6 \%$ ). The exception was the shallow sample at Site 5, which had the highest $\delta^{13} \mathrm{C}_{\text {DOC }}$ value $(-25.0 \%$ ) and trended towards a marine OM value (Lamb et al., 2006) with a DOC concentration $\left(2.1 \mathrm{mg} \mathrm{L}^{-1}\right)$ well below the average for this site, which suggests a localized source of OM that may be derived from marine sources due to its close proximity to the ocean.

\subsection{Implications}

Most studies investigate the character or carbon isotope signatures of DOC in groundwater but rarely use both techniques. Our findings showed that there are several sources of OM within this coastal aquifer, ranging from buried peat units to palaeosols, and that if both techniques were not used, these sources would not have been identified. It is important to understand the sources to estimate the contribution of subsurface carbon to the global carbon cycle. The combination of the low sorption capacity of the coastal aquifer sediments and the presence of various sources of OM together with the associated anoxic aquifer conditions appears to have limited the sorption and/or biodegradation that might be observed elsewhere in groundwater. Therefore, this study further demonstrated that the persistence of OM was found to be due to complex interactions between the OM and its environment (Schmidt et al., 2011).

The groundwater that discharges from young unconsolidated coastal environments such as these has much higher DOC concentrations than groundwater from older, deeper aquifers that have undergone a greater degree of OM processing (McDonough et al., 2020b). The degradative processes that act on freshly produced DOM can produce greenhouse gases and produce less reactive DOM that is exported (Davidson and Janssens, 2006; Zhou et al., 2018). This means that the DOM transported from this coastal system has the potential to impact the carbon budget. Moreover, sandy coastal aquifers containing palaeosol horizons are globally widespread as they formed during Holocene sea-level changes. These systems are sensitive to sea-level changes and climate-change drivers that are likely to impact DOC export from coastal systems because of changes in either the hydrology or ecosystem dynamics. The OM sources found in this system are currently saturated and anoxic. If the physicochemical conditions of the aquifer were altered, these coastal groundwater systems would then have the potential to export a 1-order-of-magnitude-higher volume of unreacted carbon to the surface than are previously realized based on the current global median DOC concentration of $1 \mathrm{mg} \mathrm{L}^{-1}$ for groundwaters (McDonough et al., 2020a). These coastal groundwater systems form a significant OM source that is largely unaccounted for in the global carbon budget. The magnitude and timing of the soil $\mathrm{C}$ reservoir change as a result of climate and land-use changes are difficult to quantify and is a large source of uncertainty in global C cycle models (Kendall and McDonnell, 1998). Therefore, studies like this that identify the sources of OM in aquifers will contribute to refining calculations in the future. 


\section{Conclusions}

The purpose of this study was to investigate the role of different OM sources and the influence of the physicochemical properties of an aquifer on groundwater DOM. This was done to identify the major controls on groundwater DOC sources and processing in a coastal groundwater system. Our results showed that groundwater DOC varied in concentration and isotopic character along a $500 \mathrm{~m}$ groundwater flow path. The average groundwater DOC concentration for this study was 5 times higher $\left(5 \mathrm{mg} \mathrm{L}^{-1}\right)$ than the global median DOC concentration for groundwaters. The concentration of DOC doubled with depth, reaching $10 \mathrm{mg} \mathrm{L}^{-1}$, but the DOM chromatographic fractions did not change significantly with depth or along the groundwater flow path. We note that the carbon isotopic composition did, however, vary slightly.

Multiple sources of organic matter were identified, including those formed during the maximum Holocene sea-level transgression such as wetland, soil, peat and palaeosols. It was found that the DOC character at this site did not follow the regional chromatography model due to OM processing with depth and along a groundwater flow path. All samples were more aromatic for their molecular weight in comparison to surface lakes, rivers and marine samples. It was also found that the physicochemical properties of the aquifer and in this case the anoxic-saturated conditions limited OM processes, leading to enhanced preservation and storage of OM. The contradiction in DOM trends when compared to the redox chemistry of the groundwater for this study challenged our current understanding of groundwater DOC mobilization and degradation in coastal aquifers. A possible explanation for not observing a decrease and change in DOM character with evolved inorganic redox chemistry is that DOM is being released from the OM sources at a higher rate than biodegradation is occurring.

In situ sources such as peats and palaeosols are the main contributor of OM to the groundwater DOC in this coastal system. The destabilization or changes in hydrology, whether by anthropogenic or natural processes, could result in increased fluxes of unreacted old carbon from deep within the peat column. Significantly, the results of this study show that understudied anoxic coastal groundwater systems have the potential to export up to 10 times more unreacted carbon to the surface than previously realized, considering the global median DOC concentration is $1 \mathrm{mg} \mathrm{L}^{-1}$ for groundwaters. These coastal groundwater sources are largely unaccounted for in the global carbon budget and are likely to play more of a role in carbon transport in the future.

Data availability. All data are presented in the tables.

Author contributions. Field sampling was undertaken by MSA, AB, KTM, DMO, HR, EB and NSZ. KTM undertook the data anal- ysis, wrote the paper and constructed the figures under the guidance of AB. LKM generated GIS files for Fig. 1 and did the PCA for Fig. 6. PO constructed the original Fig. 7, and HR provided the initial LC-OCD interpretation. All authors reviewed and provided comments on the paper.

Competing interests. The authors declare that they have no conflict of interest.

Acknowledgements. The authors would like to thank the NSW Office of Water for providing the funding for drilling and monitoring the bore installation. Hamish Studholme, Sam McCulloch and Juan Carlos Castilla-Rho did the drilling and bore installation. NSW National Parks provided the scientific license and approval for the research to be conducted within the Tomaree National Park. Nur Syahiza Zainuddin was supported by a Malaysian government PhD scholarship. Thanks go to Ellen Howley for her help with the sampling. The authors would also like to thank various ANSTO personnel such as Robert Chisari and Kelly Farrawell for analysis.

Financial support. This work has been supported by ANSTO, the Australian Research Council (ARC)/National Water Commission co-funded National Centre for Groundwater Research and Training (NCGRT), and the ARC project DP160101379.

Review statement. This paper was edited by Nandita Basu and reviewed by Hannelore Waska and one anonymous referee.

\section{References}

Appelo, C. A. J. and Postma, D.: Geochemistry, Groundwater, and Pollution, second ed., A.A. Balkema, Rotterdam, 649 pp., 2005.

Benner, R., Newell, S. Y., Maccubbin, A. E., and Hodson, R. E.: Relative contributions of bacteria and fungi to rates of degradation of lignocellulosic detritus in salt-marsh sediments, Appl. Environ. Microb., 48, 36-40, 1984.

Berner, R. A.: A new geochemical classification of sedimentary environments, J. Sediment. Res., 51, 359-365, 1981.

Bertrand, P. and Lallier-Vergès, E.: Past sedimentary organic matter accumulation and degradation controlled by productivity, Nature, 364, 786-788, 1993.

Bryan, E., Meredith, K. T., Baker, A., Andersen, M. S., Post, V. E. A., and Treble, P. C.: How water isotopes $\left({ }^{18} \mathrm{O},{ }^{2} \mathrm{H},{ }^{3} \mathrm{H}\right)$ within an island freshwater lens respond to changes in rainfall, Water Res., 170, 115301, https://doi.org/10.1016/j.watres.2019.115301, 2020.

Catalán, N., Casas-Ruiz, J. P., von Schiller, D., Proia, L., Obrador, B., Zwirnmann, E., and Marcé, R.: Biodegradation kinetics of dissolved organic matter chromatographic fractions in an intermittent river, J. Geophys. Res.-Biogeo., 122, 131-144, 2017.

Chapelle, F. H., Shen, Y., Strom, E. W., and Benner, R.: The removal kinetics of dissolved organic matter and the optical clarity of groundwater, Hydrogeol. J., 24, 1413-1422, 2016. 
Clark, I. D. and Fritz, P.: Environmental Isotopes in Hydrogeology, Taylor \& Francis, 1997.

Davidson, E. A. and Janssens, I. A.: Temperature sensitivity of soil carbon decomposition and feedbacks to climate change, Nature, 440, 165-173, 2006.

Emery, K. O., Wigley, R. L., Bartlett, A. S., Rubin, M., and Barghoorn, E. S.: Freshwater Peat on the Continental Shelf, Science, 158, 1301-1307, 1967.

Fontaine, S., Barot, S., Barré, P., Bdioui, N., Mary, B., and Rumpel, C.: Stability of organic carbon in deep soil layers controlled by fresh carbon supply, Nature, 450, 277-280, 2007.

Hashimoto T. R. and Troedson A. L.: Nelson Bay 1:100000 and $1: 25000$, Coastal Quaternary Geology Map Series. Geological Survey of New South Wales, Maitland, available at: https://search.geoscience.nsw.gov.au/product/39 (last access: 28 April 2020), 2008.

Hedges, J. I., Ertel, J. R., Quay, P. D., Grootes, P. M., Richey, J. E., Devol, A. H., Farwell, G. W., Schmidt, F. W., and Salati, E.: Organic carbon-14 in the Amazon River system, Science, 231, 1129-1131, 1986.

Hedges, J. I., Cowie, G. L., Richey, J. E., Quay, P. D., Benner, R., Strom, M., and Forsberg, B. R.: Origins and processing of organic-matter in the Amazon River as indicated by carbohydrates and amino-acid, Limnol. Oceanogr., 39, 743-761, 1994.

Howley, E.: Lignin in a coastal groundwater aquifer: a useful tracer? Bachelor of Engineering (Hons) Thesis, School of Civil and Environmental Engineering UNSW, Sydney, 2014.

Huber, S. A., Balz, A., Abert, M., and Pronk, W.: Characterisation of aquatic humic and non-humic matter with size-exclusion chromatography - organic carbon detection - organic nitrogen detection (LC-OCD-OND), Water Res., 45, 879-885, 2011.

Jones, R. L.: Late Holocene vegetational changes on the Illawarra coastal plain, New South Wales, Australia, Rev. Palaeobot. Palynol., 65, 37-46, 1990.

Keiluweit, M., Wanzek, T., Kleber, M., Nico, P., and Fendorf, S.: Anaerobic microsites have an unaccounted role in soil carbon stabilization, Nat. Commun., 8, 1771, 2017.

Kendall, C. and McDonnell, J. J.: Isotope Tracers in Catchment Hydrology, Elsevier Science, 1998.

Kerner, M., Hohenberg, H., Ertl, S., Reckermann, M., and Spitzy, A.: Self-organization of dissolved organic matter to micelle-like microparticles in river water, Nature, 422, 150-154, https://doi.org/10.1038/nature01469, 2003.

Lamb, A. L., Wilson, G. P., and Leng, M. J.: A review of coastal palaeoclimate and relative sea-level reconstructions using $\delta^{13} \mathrm{C}$ and $\mathrm{C} / \mathrm{N}$ ratios in organic material, Earth-Sci. Rev., 75, 29-57, 2006.

McDonough, L. K., Isaac, R. S., Andersen, M. S., O'Carroll, D. M., Rutlidge, H., Meredith, K., Oudone, P., Bridgeman, J., Gooddy, D. C., Sorensen, J. P. R., Lapworth, D. J., MacDonald, A. M., Ward, J., and Baker, A.: Changes in global groundwater organic carbon driven by climate change and urbanization, Nat. Commun., 11, 1279, https://doi.org/10.1038/s41467-020-149461, 2020a.

McDonough, L. K., Rutlidge, H., O'Carroll, D. M., Andersen, M. S., Meredith, K., Behnke, M. I., Spencer, R. G. M., McKenna, A. M., Marjo, C. E., Oudone, P., and Baker, A.: Characterisation of shallow groundwater dissolved organic matter in aeolian, al- luvial and fractured rock aquifers, Geochim. Cosmochim. Ac., 273, 163-176, https://doi.org/10.1016/j.gca.2020.01.022, 2020 b.

Macphail, M.: Pollen analysis of a buried organic deposit on the backshore at Fingal Bay, Port Stephens, New South Wales, Proceedings of the Linnean Society of New South Wales, 98, 222233, 1974 .

Maric, I.: Groundwater quality changes in a coastal aquifer due to groundwater abstraction: A case study. Bachelor of Engineering (Hons) Thesis, School of Civil and Environmental Engineering UNSW, Sydney, 2013.

Meredith, K., Cendón, D.I., Pigois, J.-P., Hollins, S., and Jacobsen, G.: Using ${ }^{14} \mathrm{C}$ and ${ }^{3} \mathrm{H}$ to delineate a recharge "window" into the Perth Basin aquifers, North Gnangara groundwater system, Western Australia, Sci. Total Environ., 414, 456-469, 2012.

Meredith, K. T., Han, L. F., Hollins, S. E., Cendón, D. I., Jacobsen, G. E., and Baker, A.: Evolution of chemical and isotopic composition of inorganic carbon in a complex semi-arid zone environment: Consequences for groundwater dating using radiocarbon, Geochim. Cosmochim. Ac., 188, 352-367, 2016.

Moore, S., Evans, C. D., Page, S. E., Garnett, M. H., Jones, T. G., Freeman, C., Hooijer, A., Wiltshire, A. J., Limin, S. H., and Gauci, V.: Deep instability of deforested tropical peatlands revealed by fluvial organic carbon fluxes, Nature, 493, 660-663, https://doi.org/10.1038/nature11818, 2013.

Oudone, P., Rutlidge, H., Andersen, M. S., O'Carroll, D., Cheong, S., Meredith, K., McDonough, L., Marjo, C., and Baker, A.: Characterisation and controls on mineral-sorbed organic matter from a variety of groundwater environments, EarthArXiv, https: //eartharxiv.org/ue86w/, https://doi.org/10.31223/osf.io/ue86w, 2019.

Schefuß, E., Eglinton, T. I., Spencer-Jones, C. L., Rullkötter, J., De Pol-Holz, R., Talbot, H. M., Grootes, P. M., and Schneider, R. R.: Hydrologic control of carbon cycling and aged carbon discharge in the Congo River basin, Nat. Geosci., 9, 687-690, https://doi.org/10.1038/ngeo2778, 2016.

Schmidt, M. W. I., Torn, M. S., Abiven, S., Dittmar, T., Guggenberger, G., Janssens, I. A., Kleber, M., Kögel-Knabner, I., Lehmann, J., Manning, D. A. C., Nannipieri, P., Rasse, D. P., Weiner, S., and Trumbore, S. E.: Persistence of soil organic matter as an ecosystem property, Nature, 478, 49-56, https://doi.org/10.1038/nature10386, 2011.

Shen, Y., Chapelle, F. H., Strom, E. W., and Benner, R.: Origins and bioavailability of dissolved organic matter in groundwater, Biogeochemistry, 122, 61-78, 2015.

Sloss, C. R., Murray-Wallace, C. V., and Jones, B. G.: Holocene sea-level change on the southeast coast of Australia: a review, Holocene, 17, 999-1014, 2007.

Stumm, W. and Morgan, J. J.: Aquatic chemistry, 3rd edition, Wiley and Sons, New York, 1996.

Tadros, C. V., Hughes, C. E., Crawford, J., Hollins, S. E., and Chisari, R.: Tritium in Australian precipitation: A 50 year record, J. Hydrol., 513, 262-273, 2014.

Webb, J. R., Santos, I. R., Maher, D. T., Tait, D. R., Cyronak, T., Sadat-Noori, M., Macklin, P., and Jeffrey, L. C.: Groundwater as a source of dissolved organic matter to coastal waters: Insights from radon and CDOM observations in 12 shallow coastal systems, Limnol. Oceanogr., 64, 182-196, https://doi.org/10.1002/lno.11028, 2018. 
Zhou, Y., Davidson, T. A., Yao, X., Zhang, Y., Jeppesen, E., de Souza, J. G., Wu, H., Shi, K., and Qin, B.: How autochthonous dissolved organic matter responds to eutrophication and climate warming: Evidence from a cross-continental data analysis and experiments, Earth-Sci. Rev., 185, 928-937, 2018. 